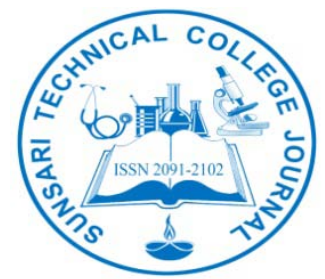

\title{
EFFECT OF INCORPORATION OF MALTED SORGHUM FLOUR ON QUALITY OF BISCUIT
}

\author{
Nischal Adhikari ${ }^{*}$, Dev Raj Acharya ${ }^{2}$ \\ ${ }^{1}$ Sunsari Technical College, Tribhuvan University, Dharan \\ ${ }^{2}$ Department of Food Technology, Sunsari Technical College, Dharan \\ *Corresponding author email: adhikari943@gmail.com
}

Received: 19.04.2015; Revised and Accepted- 06.06.2015

DOI: http://dx.doi.org/10.3126/stcj.v2i1.14796

\begin{abstract}
Sorghum (S. bicolor) collected from Dhankuta district was used for malting. Sorghum was steeped for 12 hours at Relative humidity of $70 \pm 5 \%$ and germinated at room temperature $\left(28 \pm 3^{\circ} \mathrm{C}\right)$ with repeated change of water at interval of every 8 hours for 2, 3,4,5,6 and 7 days. The germinated samples of each day were taken for kilning at the temperature scenario of $50-55^{\circ} \mathrm{C}$ until moisture reaches to $23 \% ; 70-75^{\circ} \mathrm{C}$ until moisture reaches to $12 \%$; and $90-95 \%$ until moisture reaches to $3-5 \%$. The result of enzyme activity determination showed that the sorghum germinated for 3 days has the higher enzyme activity of 27.39 units per gram dry matter. Proximate analysis of malted and unmalted flour showed significant different $(\mathrm{p}<0.05)$ in fat, ash, reducing sugar and crude fiber content. Likewise calcium and iron content of malted flour was significantly increased $(\mathrm{p}<0.05)$ than that of unmalted one with subsequent decreased $(\mathrm{p}<0.05)$ in their binder oxalate and phytate respectively. The sorghum of higher enzyme activity was then used to prepare the biscuit. Malted sorghum and wheat flour was blended in the following ratios: samples A; 30: 70, sample B; 50:50, sample C; 60:40, sample D; 0:100. The organolaptic test shows the significant difference $(\mathrm{p}<0.05)$ between these samples in terms of flavor and test. The mean sensory score was found to be higher for sample C. This suggests that the malted sorghum flour can be used for the preparation of biscuit upto $60 \%(\mathrm{w} / \mathrm{w})$ of wheat flour without alteration in texture, crispiness, appearance and overall acceptability.
\end{abstract}

\section{INTRODUCTION}

Humans have consumed bakery products for hundreds of years. Among the different bakery products, biscuits constitute the most popular group. Biscuits are confectionery dried to very low moisture content. Biscuit may be defined as a thin flat baked product made from flour, salt, sweetening agent, fat and preservatives. They are crisps, unleavened and sometimes sweet pastry produced light by the addition of baking powder or soda, sometimes with chocolate or fruit input. Biscuit can also be defined as a baked product having not less than $8 \%$ of flour content calculated ${ }^{1}$. Bohn, $1956^{2}$ stated that biscuits are termed "cookies" in USA but the Word biscuit means a small cake like bun.

Wheat flour is a principal raw material in biscuit production. Its superiority over other cereals is due to the presence of gluten. Beside the wheat flour, there are basically some ingredients that are used for biscuit production such as sugar, salt, milk, shortening, flavour and leavening. Egg improves the volume of biscuit as well as the taste and flavour. Egg and butter are also used for variety, these improves the quality of the products ${ }^{3}$.

Sorghum (Sorghum bicolor L. Moench) is a member of the subfamily Panicoideae in the family Gramineae ${ }^{4}$. Sorghum is considered the fifth most important cereal crop in the world behind wheat, rice, maize, and barley ${ }^{5}$.

Malting process, which involves soaking, germination and drying, aims to change grains into malt with high enzymes and vitamins content. Malting induces important beneficial biochemical changes in sorghum grains. Indeed, soaking generates grain softening and increase water availability. The enzymes produce during germination lead to the hydrolysis of starch and proteins with release of sugar and amino acids directly available. Proteolytic enzymes improve amino acid availability, particularly lysine, methionine and tryptophan that are lacking in cereals. From 
the study, it has been shown that malting process can contribute to the reduction of phytate level of grain and improve iron and zinc availability ${ }^{6}$. Wheat flour used for the production of biscuits is deficient in several nutrients including some vitamins, mineral elements as well as dietary fiber ${ }^{7}$. Wheat flour lacks certain essential amino acids such as lysine, tryptophan and threonine ${ }^{8}$; hence, the low nutritive value of biscuits is an issue of great concern because biscuits are the most commonly eaten snacks by school children who need more protein per unit body weight than adults.

\section{MATERIALS AND METHOD}

Malting was done according to Ogbonna (2012) except cleaning. Gravity separation was replaced with traditional winnowing. Steeping was done at room temperature as temperature does not affect the diastatic power of malt ${ }^{9}$. Cleaned seeds were transferred to the stainless vessel and water was added 3 times that of sorghum. The grain was steeped for 12 hours at room temperature $\left(27 \pm 3^{\circ} \mathrm{C}, 70 \pm 5 \%\right.$ $\mathrm{RH})$ and drained to remove the excess water. The steeped grain were spread over plastic trays and covered with moistened muslin cloth and kept for germination at room temperature and RH 70 $5 \%$ for 24 h. During germination, the cereal was moistened by sprinkling water at $8 \mathrm{hr}$ interval and mixed gently in order to equalize temperature and aerate the mass. Sorghum germinated for different time (viz; 24, 48, 72, 96, 120, 144, and 168 hrs) were $\mathrm{dried} /$ kilned to stop further germination. Drying was carried out in a cabinet dryer in three different stages as follows:

- First stage, dry the germinated grain at $50-55^{\circ} \mathrm{C}$ up to moisture content of $23 \%$;

-Second stage, dry the dried grain at $70-75^{\circ} \mathrm{C}$ up to moisture content of $12 \%$ and;

-At third stage, it is dried at $90-95^{\circ} \mathrm{C}$ up to moisture content of 3 to $5 \%$.

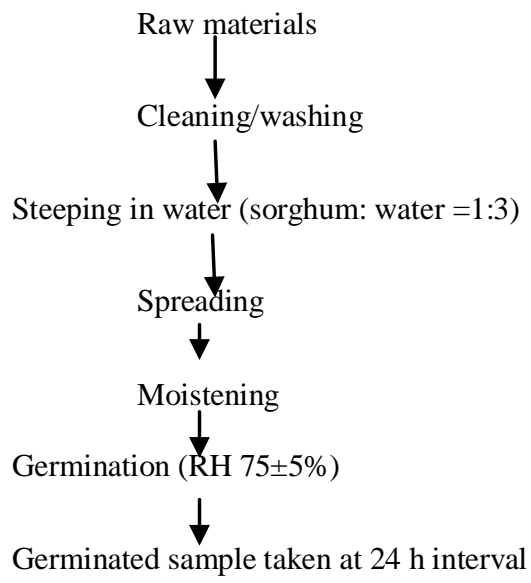

Drying in hot air oven (Cabinet drier) in three stages (24,

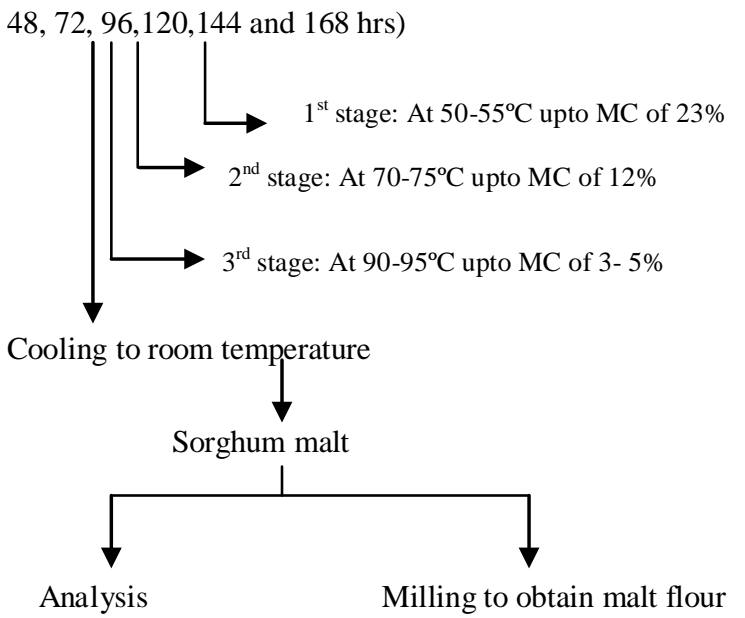

Figure 1: Flow diagram for preparation of sorghum malt

Biscuit was prepared using creaming method as described by Maskey (2002) ${ }^{10}$ using the following ingredient in following proportions:

Flour blends-

Sugar$100 \mathrm{~g}$

Shortening$30 \mathrm{~g}$

Salt$20 \mathrm{~g}$

Sodium bicarbonate$0.5 \mathrm{~g}$

Ammonium bicarbonate-

$1 \mathrm{~g}$

Water-

$20 \mathrm{ml}$

Skimmed milk powder-

Syrup

$2 \mathrm{~g}$

$5 \mathrm{~g}$

Malted sorghum and wheat flour was blended in the following ratios: samples A; 30: 70, sample B; 50:50, sample C; 60:40, sample D; 100:0.

The biscuit was baked in an electric oven maintained at suitable temperature profile. The time taken for complete baking is around 6 minutes. The baked biscuits were then collected, cooled and packed into bags for further analysis.

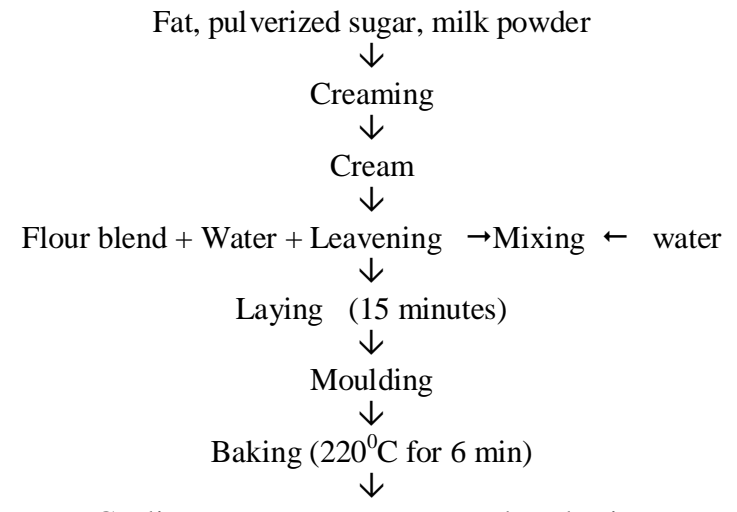

Cooling to room temperature and Packaging

Figure.2 Flow chart for the production of biscuit 
Methods of AOAC (2005) $)^{11}$ were followed for the proximate analysis of sorghum and biscuits as well as for the determination of oxalic acid. Amylase activity and phytic acid were determined by using the method described by Sadasivan and Manickam ${ }^{12}$. Iron and Calcium were determined by using the method described in Rangana ${ }^{13}$. Sensory evaluation for overall acceptability was carried out with semi-trained panelist using hedonic rating test. All the data obtained in this research work was analysis by statistical program Genstat which was developed by Lawes Agricultural Trust . From this mean ANOVA (No blocking at 5\% Level of significance), LSD and interaction effects will be obtained to determine whether the sample are significantly different from each other and also to determine which one is superior among them.

\section{RESULT AND DISCUSSION}

\section{Enzyme activity}

Statistical analysis showed that the amylase activity of sorghum is significantly different for each day of germination $(p<0.05)$. The LSD shows enzyme activity of sorghum germinated for 72 hours is superior compare to other. Malting significantly increased the enzyme activity. Sarwar (2010) ${ }^{14}$ and Ogbonna et al (2012) also found the same pattern of graph for the plot of enzyme activity versus day of germination.

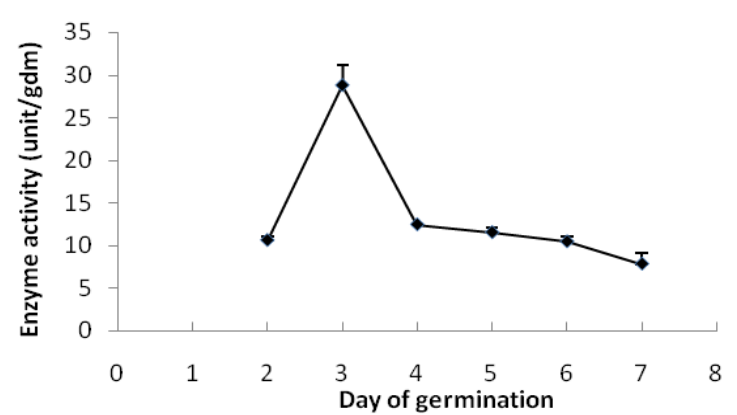

Figure 3. enzyme activity vs day of germination

\section{Proximate Composition}

Table 1: Proximate composition of malted and unmalted sorghum flour

\begin{tabular}{|c|c|c|c|}
\hline Samples $\rightarrow$ Composition (\%) $\downarrow$ & Unmalted Flour & Malted flour & LSD (5\%) \\
\hline Moisture content & $12.2(0.265)^{a}$ & $5.5(0.080)^{b}$ & 0.7217 \\
\hline Protein & $10.2(0.161)^{\mathrm{a}}$ & $10.21(0.930)^{\mathrm{a}}$ & 2.385 \\
\hline Carbohydrate & $71.74(0.181)^{\mathrm{a}}$ & $72.34(1.071)^{\mathrm{a}}$ & 2.215 \\
\hline Fat & $3.3(0.020)^{\mathrm{a}}$ & $6.4(0.101)^{\mathrm{b}}$ & 0.3012 \\
\hline Ash & $0.56(0.026)^{a}$ & $2.1(0.046)^{b}$ & 0.06572 \\
\hline Reducing sugar & $1.04(0.010)^{\mathrm{a}}$ & $13.45(0.223)^{\mathrm{b}}$ & 0.5789 \\
\hline Crude fiber & $2(0.036)^{a}$ & $3.45(0.101)^{b}$ & 0.3415 \\
\hline
\end{tabular}

*Values are means of triplicate determinations \pm S.D.

${ }^{a b}$ Means with different superscripts on the same column are significantly different at $p \leq 0.05$.

The moisture content increased initially during germination. But the moisture content of malted flour is decreased significantly $(\mathrm{p} \leq 0.05)$ by $54.91 \%$ which is due to enzyme inactivation process during malting i.e. kilning. The hydration process during germination activated a wide array of enzyme systems which hydrolysed and solubilised food reserves. There was no significant difference on the crude protein content of the two flours (F.Pr. $=0.987$ ). The carbohydrate content of the malted flour was not found significantly different ( $\mathrm{p} \geq 0.05$ ) from that of the un-malted flour. But the reducing sugar of malted sample increased significantly ( $\mathrm{k} \leq 0.05$ ). This significant increase could be due to activity of enzymes. The carbohydrates may have been digested into simple sugars by amylolytic enzymes ${ }^{15}$. The total ash content of the malted flour sample increased 
significantly (〔0.05) than that of the unmalted flour sample. This may be due to result of enzyme solubilisation and leaching of the anti-nutritional factors binding them through leaching $^{16,17}$.

The crude fiber content of the malted samples increased significantly $(\mathrm{p} \leq 0.05)$ by $72.5 \%$. This increase could be attributed to increased bran matter and the building of dry matter during the growth and development (germination) of the plant. A highly significant ( $\mathrm{p} \leq 0.05)$ increase of $93.93 \%$ in the crude fat levels of the malted samples over the unmalted was observed which may be due to its proportional increase as a result of decrease in the other food reserves like non-reducing carbohydrate.

Thus the malting condition significantly affects the proximate composition of the sorghum grist. The result found is of same type as that was found by Ogbonna et al (2012) during the malting of Sorghum (steeped for 24 hours; germinated for 72 hours and kilned at varying degree of temperature as mentioned above). Similarly, Idris et al. $(2005)^{16}$ and Alemu (2009) ${ }^{17}$ have also found to change in proximate composition in same manner.

\section{Mineral Composition}

The result shows that calcium is increased by $157 \%$ and iron is increased by $93.70 \%$. This increment in the content of the minerals is possibly due to result of enzyme solubilisation and leaching of the anti-nutritional factors binding them through leaching had also found same percentage of increment on calcium and iron content during malting (steeped for 24 hours; germinated for 72 hours) $)^{4,16,9}$.

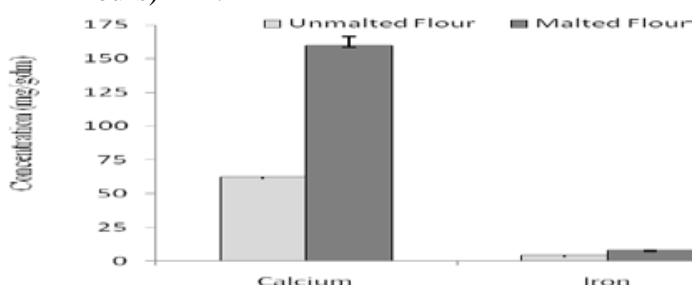

Anti-nutritional factors: Oxalate and Phytate

The average oxalate content was found to be $12.60 \%$ and $8.29 \%$ and the average phytate level was found to be $1.50 \%$ and $0.51 \%$ of total anti-nutritional component for unmalted and malted sorghum flour samples respectively. Statistical analysis showed that the malting had significant effect $(\mathrm{p}<$ 0.05) on both oxalate and phytate level of sorghum.

Malting significantly decreased the oxalate and phytate content of sorghum, which is similar to the result reported by Ogbonna et al. (2012).

Table 2: Change in oxalate and phytate content in sorghum during malting

\begin{tabular}{|lll|}
\hline Samples & Oxalate (\%) & Phytate (\%) \\
\hline $\begin{array}{l}\text { Un-malted } \\
\text { sorghum flour }\end{array}$ & $12.61(0.251)^{\mathrm{a}}$ & $1.50(0.085)^{\mathrm{a}}$ \\
$\begin{array}{l}\text { Malted sorghum } \\
\text { flour }\end{array}$ & $8.29(0.147)^{\mathrm{b}}$ & $0.51(0.003)^{\mathrm{b}}$ \\
\hline LSD & 0.989 & 0.2048 \\
\hline
\end{tabular}

\section{Sensory Analysis}

Statistical analysis showed that there is no significant different between these formulations A, B, C and D in terms of appearance, texture, crispiness and overall acceptability. But the taste and flavor of A, B and C are significantly different from sample D. Here, our objective is to incorporate maximum proportion of malted sorghum flour without alteration in overall acceptability and other sensory parameters. Thus, formulation $\mathrm{C}$ was selected as the best formulation.

Table 3. Proximate Composition of the biscuit
(formulation C)
\begin{tabular}{|lc|}
\hline Parameters & \%Composition \\
\hline Moisture content & $2.65(0.45)$ \\
Protein & $6.25(0.80)$ \\
Fat & $15.80(1.05)$ \\
Reducing sugar & $21.35(2.25)$ \\
Other carbohydrate & $52.81(1.50)$ \\
Salt & $1.14(0.13)$ \\
\hline
\end{tabular}

According to Kent and Evers (2004) ${ }^{18}$, soft dough biscuits generally contain high fat (15-25\%) and are low in moisture. Thus the final product with 60 parts of malted sorghum flour falls within the range of soft dough biscuits. The low moisture content in biscuits will minimize the microbial growth and the shelf-life of the product will be longer if high moisture and air barrier packaging material are used (Kent, 1983).

\section{CONCLUSION}

The work was done under controlled condition and on a small scale, its generalization may warrant some reservations. Furthermore, Anti-nutritional factors like phytic acid and oxalic acid in sorghum can be significantly 
$(p<0.05)$ reduced by malting, thus increasing the nutrient availability. Malting of sorghum significantly increases amylase activity, increasing the level of reducing sugar.Sorghum flour can be incorporated to the extent of $60 \%(\mathrm{w} / \mathrm{w})$ in wheat flour to produce biscuit and the overall acceptability of biscuit from malted and unmalted sorghum does not differ significantly but the taste and flavor as well nutritional attributes in the former is greatly improved. Finally, based on panelists' comments, the composite biscuit was very unique and tasty. This indicates to ample possibilities for value-addition of sorghum, thereby helping ensure food security amongst the poor.

\section{ACKNOWLEDGEMENT}

We would like to offer special thanks to Lecturer Ram Sovit Yadav (Head of department, Department of Food Technology, Sunsari Technical College) for his advice, and encouragement during the work. we also express humble gratitude to Mr. Bunty Maskey, Lecturer of Sunsari Technical College and to Mr. Prakash Adhikari of Pashupati Biscuit Industry Pvt. Ltd., Duhabi, Sunsari and colleagues Santosh Katwal, Bharat N Shrestha and Deepa Dahal for their generous cooperation and amicable accompany.

\section{REFERENCES}

1. Kent, N.L. Technology of cereals, Pergamon Press, Oxford, 1983; 3ed.

2. Bohn, R.M. Biscuit and cracker production: A manual on the Technology and practice of biscuit, cracker and cookie manufacture including formulas, American Trade Publishing Company, New York, 1956; 1ed.

3. Terrell, NJ. The technology of bakeries. Applied science publishers Ltd., London, 1972.

4. Ogbonna, A. et al, Effect of malting condition on the nutritional and anti-nutritional factors of sorghum grist. Department of Food Science and Technology, University of Uyo, 2012.

5. ICRISAT (International Crop Research Institute for Semi-Arid Tropics). The world sorghum and millets: Facts and, trends and outlook. Patancheru, India, 1996; pp-1-25.

6. Malleshi, N.G, Desikachar, H.S.R. and Venkat Rao, S. Protein quality evaluation of a weaning food based on malted ragy and green gram. Qual. PLANT. Plant Foods Hum. Nuta. 36, 1986; pp-223-230.

7. Awan, J.A. Salim-ur-Rehman, E. Ullah, M. Siddique, T. Aziz. Nutrition of wheat flour in Islamic perspective. JAPS, 1991; 1(2): 1-7

8. Kent, N.L. Technology of cereals, Pergamon Press, Oxford, 1983; 3ed.
9. N. Phattanakulkaewmorie. Chemical Compositions and Physico-Chemical Properties of Malted Sorghum Flour and Characteristics of Gluten Free Bread. Faculty of Food Technology, Mahasarakham University, Kantharawichai District, Mahasarakham, Thailand, 44150, 1991.

10. Maskey, B. Preparation of coconut biscuit and its quality evaluation. B. Tech. (Food) Dissertation, Central Campus of Technology, T.U., Nepal, 2002.

11. AOAC. Official methods of analysis, 18ed. Association of official analytical chemists, Washington DC, 2005.

12. Sadasivam, S. and Manikam, A. In: "Biochemical Methods for Agricultural Sciences”, Wiley Eastern Limited, New Delhi, 1991; pp. 122-124.

13. Ranganna, S. Handbook of analysis and quality control for fruit and vegetable products, Tata McGraw Hill Pub. Co. Ltd., New Delhi, 2007; 22ed.

14. Sarwar. G. Preparation and quality evaluation of composite bread from wheat flour and finger millet (Elusine coracana L.) flour (Malted and unmalted). B. Tech. (Food) Dissertation, Central Campus of Technology, T.U., Nepal, 2010.

15. Elkhier, M.K.S., Hamid, A.O. Effect of malting on the chemical constituents, antinutrition factors and ash composition of two sorghum cultivars (feterita and tabat) grown in Sudan, 2008.

16. Idris, W.H., A Rahaman, S.M., Elmaki, H.B., Babikar, E.E., Eltinay, A.H. Effect of malt pre-treatment on $\mathrm{HCl}$ extractability of calcium, phosphorus and iron of sorghum (Sorghum bicolor) cultivars. International Journal of Food Science and Technology, 2007; , 42:194-199 http://dx.doi.org/10.1111/j.1365-2621.2006.01207.x

17. Alemu KM. The effect of natural fermentation on some anti nutritional factors, minerals, proximate composition and sensory characteristics in sorghum based weaning foods. M.Sc. thesis, Addis Ababa University, Ethiopia, 2009.

18. Kent N.L. and Evers A.D. Bread-baking technology. In: “Technology of Cereals", Woodhead Publ. Ltd., Cambridge, England, 2004; 4ed, pp: 191-217.

Cite this article as: Adhikari N, Acharya DR. Effect of Incorporation of Malted Sorghum flour on quality of biscuit. STCJ 2015; 2(1):33-37. 